\title{
Immunofluorescent test for simultaneous detection of Edwardsiella ictaluri and Flavobacterium columnare
}

\author{
Victor S. Panangala ${ }^{1, *}$, Richard A. Shelby ${ }^{1}$, Craig A. Shoemaker ${ }^{1}$, Phillip H. Klesius ${ }^{1}$, \\ Amitava Mitra' ${ }^{2}$, Edward E. Morrison ${ }^{3}$
}

${ }^{1}$ Aquatic Animal Health Research Unit, US Department of Agriculture, Agricultural Research Service, PO Box 952, Auburn, Alabama 36831, USA

${ }^{2}$ College of Business, and ${ }^{3}$ Department of Anatomy, Physiology and Pharmacology, Auburn University, Auburn, Alabama 36849, USA

\begin{abstract}
Enteric septicemia of catfish (ESC) and columnaris disease are 2 bacterial diseases significantly affecting the aquaculture industry, and thus rapid diagnosis of disease is imperative for making judicious management decisions. A rapid indirect fluorescent antibody (IFA) test with antibody conjugated fluorochromes having 2 different spectral properties (Alexa Fluor 488-emitting green fluorescence, and Alexa Fluor 594-emitting red fluorescence) was compared with bacteriological culture (accepted standard) for simultaneous detection of Edwardsiella ictaluri (EI) and Flavobacterium columnare $(F C)$ in 3 groups of experimentally infected channel catfish (Ictalurus punctatus Rafinesque), and a fourth group that acquired an aquarium-infection with $F$. columnare. A total of 303 samples (derived from kidney, brain and nares) from 101 fish were concurrently examined by both tests. Fish in the 3 experimentally infected groups (I to III) were culture positive for the bacteria with which they were infected, and fish in Group IV, (the spontaneously infected fish) revealed $F$. columnare only. The IFA test compared favorably in sensitivity $(E I=80.7 \% ; F C=87.2 \%)$ and specificity $(E I=83.9 \% ; F C=88.9 \%)$ with the standard bacteriological culture. The positive predictive value $(E I=96.2 \%$ Group I, 90.8\% Group II, 93.7\% Groups I and II combined; $F C=95.2 \%$ Group II, 95.3\% Groups II, III and IV combined) was high, while the negative predictive value $(E I=$ $66.7 \%$ Group I, 31.3\% Group II, 59.5\% Groups I and II combined; FC $=73.7 \%$ Group II, $72.7 \%$ Groups II, III and IV combined) was relatively low. The IFA test will serve as an efficient tool for rapid simultaneous detection of E. ictaluri and F. columnare in outbreaks of disease.
\end{abstract}

KEY WORDS: Edwardsiella ictaluri $\cdot$ Flavobacterium columnare $\cdot$ Immunofluorescent test

Resale or republication not permitted without written consent of the publisher

\section{INTRODUCTION}

Edwardsiella ictaluri and Flavobacterium columnare are 2 major bacterial pathogens that cause a devastating economic impact on the fish farming industry (Thune \& Stanley 1993, USDA 2003). Although the disease symptoms differ, the morbidity and mortality resulting from infections by these organisms are significantly high (National Animal Health Monitoring System, available at: www.aphis.usda.gov/vs/ceah/cahm/aquaculture/ catfish1.pdf). E. ictaluri, belonging to the Enterobacteriaceae family, causes enteric septicemia in the channel catfish Ictalurus punctatus Rafinesque and infrequently infects other food fishes (Plumb \& Sanchez 1983) and some ornamental species (Humphrey et al. 1986). F. columnare, previously known as Flexibacter columnaris (Bernardet \& Grimont 1989), belongs to the family Flavobacteriaceae (Bernardet et al. 1996, Schreckenberger et al. 2003), is comprised of 3 or possibly 4 distinct genogroups (Arias et al. 2004), and causes columnaris disease (Plumb 1999). Compared to E. ictaluri, which is an obligate pathogen predominately infecting ictalurid species, F. columnare has a broader host range, with 
recorded infections in over 36 species of fishes throughout the world (Anderson \& Conroy 1969). Both organisms are ubiquitous in intensive aquaculture environments, and environmental stresses, including poor water quality, high stocking density and inadequate pond aeration contribute to disease outbreaks (Thune \& Stanley 1993, Wise et al. 1993). Both organisms also thrive between 20 and $28^{\circ} \mathrm{C}$, making spring and autumn the most conducive periods for outbreaks of disease in intensive catfish farming regions (Durborow et al. 1998; Office International des Epizooties [OIE] 2003, available at: www.oie.int/eng/normes/fmanual/A_00029.htm). Characteristic visible symptoms have been described, but are not pathognomonic. Therefore, clinical identification of the etiologic agents is required.

Bacterial culture on selective or nonselective media and biochemical characterization has traditionally been employed for microbial diagnosis (OIE see: www. oie.int/eng/normes/fmanual/A_00029.htm). However, culture techniques require several days for a definitive diagnosis. Immunological techniques such as the agglutination test (Plumb \& Vinitnantharat 1989) and enzyme-linked immunoassay (ELISA) (Waterstrat et al. 1989, Klesius 1993, Shoemaker et al. 2003) have been used with limited success, partly due to the paucity of commercially available reagents for aquatic species and the lack of standardized procedures. Innovative molecular biological techniques have recently found a place as more reliable and accurate means for diagnosis of enteric septicemic disease of catfish (ESC) (Bader et al. 1998, Bilodeau et al. 2003) and columnaris disease (Bader et al. 2003, Welker et al. 2005), but these techniques are costly, demand precise methodology, and require skilled personnel. Since ESC and columnaris disease are the 2 main causes for high morbidity and mortality in farm raised catfish Ictalurus punctatus, the focus of this study was to develop a rapid, sensitive test using a combination of antibody-conjugated fluorochromes for simultaneous detection of Edwardsiella ictaluri and Flavobacterium columnare in infected fishes.

\section{MATERIALS AND METHODS}

Fish husbandry and maintenance. Juvenile channel catfish ( 5 to $8 \mathrm{~g})$, were obtained from disease-free stock (National Warmwater Aquaculture Center, Strain 103), reared at our laboratory and tested negative by bacteriological culture for Edwardsiella ictaluri, Flavobacterium columnare and other common catfishpathogenic bacteria (E. tarda, Aeromonas hydrophila, Streptococcus iniae, and Yersinia ruckeri). The fish were maintained in $185 \mathrm{l}$ glass aquaria with flow-through declorinated tap water, constant aeration, a water- temperature range of $26 \pm 2^{\circ} \mathrm{C}$ and a $12: 12 \mathrm{~h}$ light:dark photoperiod. A commercial diet (Aquamax Grower 400) was fed daily to satiation. The fish were acclimated under these conditions for $2 \mathrm{wk}$ prior to the experiments. At the beginning of the experiments, the fish were moved to separate housing, randomized into separate treatment groups, and maintained as described above.

Infection of fish and sample collection. Samples for bacteriological examination and for the indirect fluorescent antibody (IFA) tests were derived from 3 experimental groups of fish, and a fourth group that spontaneously succumbed to an aquarium-acquired columnaris disease. Group I comprised fish that were maintained in a cross-protection study and immunized and challenged as follows: (1) We immunized 25 fish ( $~ 8$ to $10 \mathrm{~g}$ in weight) with Edwardsiella ictaluri ATCC (American Type Culture Collection) Type Strain 33202. For immersion-immunization, $15 \mathrm{ml}$ of a broth culture of E. ictaluri (ATCC-33202) containing $\sim 1 \times 10^{6}$ colony forming units (CFU) ml ${ }^{-1}$ were added to $15.1 \mathrm{l}$ of water containing the fish and allowed to remain in contact for $15 \mathrm{~min}$. The fish were subsequently removed and returned to the aquaria and monitored for $28 \mathrm{~d}$. On Day 28 , the fish that remained alive were challenged by immersion with a broth culture of E. ictaluri (AL 93-58, an isolate from a diseased catfish in Alabama). We added $40 \mathrm{ml}$ of broth culture containing $\sim 2 \times 10^{7} \mathrm{CFU} \mathrm{ml}^{-1}$ to $4 \mathrm{l}$ of water containing the fish, which were left for $30 \mathrm{~min}$. Following challenge, the fish were returned to their aquaria and monitored for $21 \mathrm{~d}$. (2) A second batch of 25 fish were similarly immunized with E. ictaluri ATCC-33202 and challenged as above with E. ictaluri (EILO), an isolate from a walking catfish Clarias batrachus in Thailand (Kasornchandra et al. 1987). (3) A third batch of 25 fish were treated with sterile broth and challenged with E. ictaluri AL 93-58, and (4) a fourth batch, of 25 fish were treated with sterile broth and challenged with $E$. ictaluri, EILO. (5) A batch of 25 fish was maintained as an uninfected control. The immunization and challenge procedures were similar in Batches 1 to 5, and only the dead fish following challenge were sampled. Group II, Batch 1, consisted of 15 ( 8 to $10 \mathrm{~g}$ ) catfish that were infected by intraperitoneal (i.p.) injection of broth culture containing approximately equal numbers $\left(\sim 1 \times 10^{9} \mathrm{CFU}\right.$ $\mathrm{ml}^{-1}$ ) of E. ictaluri AL 93-58 and Flavobacterium columnare ARS-1 (isolated in 1996 from a catfish at the USDA, Aquatic Animal Health Research Unit, Auburn, Alabama). Each inoculum was administered separately in a volume of $100 \mathrm{\mu l}$ per fish. Group II, Batch 2, consisted of 12 fish that were injected i.p. with a mixture containing $1 \times 10^{9} \mathrm{CFU} \mathrm{ml}^{-1}$ of both E. ictaluri AL 93-58 and F. columnare ALG-530 (isolated in 2000 from a channel catfish at the Alabama Fish Farming Center, Greensboro, Alabama) in a volume of $100 \mu$ l per fish. Group III consisted of 12 ( 8 to $10 \mathrm{~g})$ catfish that were infected by 
i.p. injection of $100 \mu \mathrm{l}$ of a broth culture of $\sim 1 \times 10^{9}$ CFU ml ${ }^{-1}$ of $F$. columnare ARS-1. Group IV consisted of 15 catfish ( $~ 5$ to $7 \mathrm{~g}$ ) that died of spontaneously acquired columnaris disease in a separate aquarium.

Except for the control fish in Group I, Batch 5, which were euthanized using tricaine methanesulfonate (Western Chemical) at a concentration of $100 \mathrm{mg} \mathrm{l}^{-1}$ of water prior to sample collection, fish in all other groups were sampled after death from bacterial infection. For bacterial culture, the external surface of the fish was swabbed with $70 \%$ alcohol and samples collected with a $1 \mu \mathrm{l}$ sterile loop from the dissected kidney, brain and nares. In parallel, for microscopic examination, impression smears were made on glass slides from the same 3 tissues. Controls included smears made from known pure cultures of Escherichia coli, Yersinia ruckeri, Edwardsiella tarda, Pseudomonas aeruginosa, and Aeromonas hydrophila. Smears from known positive cultures of Edwardsiella ictaluri and Flavobacterium columnare, devoid of primary antibody treatment, were also included as controls in the IFA tests. Bacteriological culturing was done independently by 1 observer, while the IFA tests were performed and evaluated by a second observer. Thus, all evaluations were conducted blind.

Bacterial culture and identification. Samples collected from the kidney, brain and nares were streaked on Shieh agar (Shieh 1980), modified by replacing peptone with tryptone (Difco) and omitting the supplements $\mathrm{BaCl}_{2} \cdot \mathrm{H}_{2} \mathrm{O}, \mathrm{K}_{2} \mathrm{HPO}_{4}, \mathrm{NaCl}, \mathrm{KCl}$ and $\mathrm{Mn}$ for selective isolation of Flavobacterium columnare. For isolation of Edwardsiella ictaluri, Shotts selective medium (Shotts \& Waltman 1990) was used. Gramstained smears from agar-grown colonies were examined microscopically and $10 \%$ of isolates (selected randomly) were examined for the biochemical characteristics described for each species, F. columnare (Decostere et al. 1998) and E. ictaluri (Farmer 2003). Isolates were also randomly examined for their fatty acid methyl ester profiles and compared with standard patterns determined for each bacterium (Klesius et al. 2003, Shoemaker et al. 2005).

Polyclonal and monoclonal antibodies. Polyclonal antiserum against Flavobacterium columnare ARS-1 was prepared by immunization of goats according to the procedure described by Triftshauser et al. (1970), with modifications. Briefly, F. columnare ARS 1 grown in Shieh broth was harvested by centrifugation at $3000 \times g$ for $15 \mathrm{~min}$ and sonicated with a sonifier (Branson) on ice for $60 \mathrm{~s}$. The total protein content was measured spectrophotometrically (Smith et al. 1985) using the bicinchronic acid (BCA) protein assay reagent kit (Pierce Biotechnology) and adjusted to $1 \mathrm{mg} \mathrm{ml}^{-1}$ with sterile phosphate buffered saline (PBS), pH 7.2. We immunized 3 adult male goats with $100 \mathrm{mg} \mathrm{ml}^{-1}$ each of the antigen emulsi- fied with an equal volume of Freund's complete adjuvant (Sigma), administered by subcutaneous injection. The goats were bled at $16 \mathrm{~d}$ following immunization, and the individual producing the highest antibody titer to 18 representative isolates of $F$. columnare (measured by ELISA: Shoemaker et al. 2003) was booster immunized with the antigen emulsified in Freund's incomplete adjuvant (Sigma) on Days 19 and 40 following primary immunization. Blood was collected $1 \mathrm{wk}$ after the final immunization from the jugular vein using a hypodermic syringe, and the serum was separated by centrifugation at $1000 \times g$ for $8 \mathrm{~min}$. The serum immunoglobulin IgG fraction was purified by immunoaffinity chromatography using a Protein G antibody purification column (Pierce). The purified anti-F. columnare IgG was used as primary antibody in the IFA test. The monoclonal antibody (MAb) specific for Edwardsiella ictaluri, AA224, was developed at the Aquatic Animal Health Research Unit, Auburn, Alabama, by Klesius \& Horst (1991). Tissue culture fluid containing the MAb was concentrated by filtration through stirred cell (Amicon) membrane filtration units and used as primary antibody in the IFA test.

Sodium dodecyl sulfate-polyacrylamide gel electrophoresis (SDS-PAGE) and immunoblotting. SDSPAGE was carried out by the procedure of Laemmli (1970) using Criterion (Bio-Rad) precast, 10 to $20 \%$ linear gradient slab gels. Briefly, whole bacteria (Edwardsiella ictaluri or Flavobacterium columnare and other select bacteria) were suspended in Laemmli sample buffer $(2 \% \mathrm{w} / \mathrm{v}$ SDS, $1 \mathrm{M}$ Tris $\mathrm{HCl} \mathrm{pH} \mathrm{6.8,} 10 \% \mathrm{v} / \mathrm{v}$ glycerol and $0.005 \%$ w/v bromophenol blue) and boiled for 1 to $2 \mathrm{~min}$. We loaded $30 \mu \mathrm{l}$ of each sample at a protein concentration of $\sim 830 \mu \mathrm{g} \mathrm{ml}^{-1}$ onto the gel followed by electrophoresis at $175 \mathrm{~V}$ (constant voltage) at $15^{\circ} \mathrm{C}$ for $\sim 1.5 \mathrm{~h}$. Unstained gels containing the resolved polypeptides were electroblotted onto nitrocellulose membranes according to the method of Towbin el al. (1979), using a Criterion (Bio-Rad) electroblotting unit with a setting of $100 \mathrm{~V}$ for $30 \mathrm{~min}$. Nitrocellulose membranes containing the protein blots were equilibrated for 30 min in StartingBlock (Pierce) blocking buffer, rinsed, and treated with 1:100 dilution of the MAb AA224 for probing E. ictaluri blots and polyclonal goat anti-F. columnare diluted 1:2000 for probing $F$. columnare blots. Horseradish peroxidaseconjugated rabbit anti-mouse, immunoglobulin IgG or horseradish peroxidase-conjugated rabbit anti-goat IgG (Jackson ImmunoResearch) at a dilution of 1:10 000 was used as secondary antibody. Specific antibodybound epitopes were detected by treating the blots with the chromogenic substrate 4-chloro-1-naphthol (Bio-Rad). Additionally, blots made from protein profiles of select fish-pathogenic organisms (Aeromonas hydrophila, Streptococcus iniae, Yersinia ruckeri, Edwardsiella tarda) were also probed with the MAb 
AA224 or polyclonal goat antiserum to detect any crossreactivity.

Immunofluorescence staining and microscopy. Impression smears made on glass Fluoro slides (Erie Scientific) with two $15 \mathrm{~mm}$ circles, were air dried and heat fixed. Each circle was flooded with $50 \mu \mathrm{l}$ of the primary antibody MAb AA224 (diluted 1:100 in PBS) and incubated for $45 \mathrm{~min}$. The slides were rinsed 3 times with PBS, air dried and the circles flooded with $50 \mu$ of polyclonal goat anti-Flavobacterium columnare antibody (diluted 1:10 in PBS) and incubated for $45 \mathrm{~min}$. The slides were rinsed as before, air dried, flooded with a mixture of fluorochrome-conjugated secondary antibodies (Alexa Fluor 488-conjugated rabbit anti-mouse IgG and Alexa Fluor 594-conjugated rabbit anti-goat IgG, yielding green and red fluorescence respectively, Molecular Probes), diluted 1:400 in PBS, and incubated for $45 \mathrm{~min}$. All incubation steps were carried out at room temperature under subdued light. The slides were rinsed as above, air dried and mounted with cover slips fixed with Gel/Mount (Biomeda). Slides were examined with a Nikon Eclipse $800 \mathrm{M}$ epifluorescence microscope (Nikon) fitted with 51006 FITC/Texas Red, blue /green dual band excitation and emission filter combinations. Digital images were captured with a charge coupled device (CCD) camera using the 'Spot Advanced' program (Diagnostic Instruments). A minimum of 20 fields per smear were examined at $1000 \times$ magnification with a 15 to $20 \mathrm{~min}$ observation time per slide. Slides made from smears of Edwardsiella ictaluri mixed with other select Gramnegative organisms were stained as above and examined with an Olympus BX41 epifluorescence microscope (Olympus) fitted with a CytoViva ${ }^{150}$ (Aetos Technologies) illumination device to demonstrate fluorescence positive and negative bacteria within the same field.
Tabulation of observations and statistical analysis. The bacteriological culture (BC) and IFA test results were tabulated for each sample and the total number of samples positive and/or negative for each bacterium (i.e. Edwardsiella ictaluri and/or Flavobacterium columnare) over the total number of samples in each experimental group (I to IV) was recorded. Validation of the results was based on the calculation of diagnostic sensitivity and specificity associated with the positive/ negative categorical data using the 2 -way $(2 \times 2)$ table described in the manual of diagnostic tests for aquatic animals (OIE see www.oie.int/eng/normes/fmanual/ A_00029.htm). The relative efficiencies of the IFA test were determined by using the $\mathrm{BC}$ as the standard. Sample pairs that were both BC-positive and IFA-positive were considered to be true positive (TP), BC-negative and IFA-positive pairs were false positive (FP), BCpositive and IFA-negative pairs were false negative (FN) and sample pairs that were BC-negative and IFAnegative were regarded as true negative (TN). Test sensitivity (Sens), specificity (Spec) and predictive values were calculated as: Sens $=[\mathrm{TP} /(\mathrm{TP}+\mathrm{FN})] \times 100, \mathrm{Spec}=$ $[\mathrm{TN} /(\mathrm{TN}+\mathrm{FP})] \times 100$; positive predictive value $(\mathrm{PPV})=$ $[\mathrm{TP} /(\mathrm{TP}+\mathrm{FP})] \times 100$, and negative predictive value $(\mathrm{NPV})=[\mathrm{TN} /(\mathrm{TN}+\mathrm{FN})] \times 100$. The Z-test $($ Snedecor \& Cochran 1989) was used for statistical analysis of data and a $p$-value of $\leq 0.05$ was considered significant.

\section{RESULTS}

A total of 303 samples (derived from kidney, brain and nares) from 101 fish were examined in parallel by bacteriological culture and the IFA test for Edwardsiella ictaluri (EI) and Flavobacterium columnare (FC). All bacteriological culture and IFA test results are presented in Table 1. Isolates were readily differentiated

Table 1. Ictalurus punctatus infected with Edwardsiella ictaluri (EI) and Flavobacterium columnare (FC). Bacteriological culture and indirect fluorescent antibody (IFA) test results for respective fish groups. Values are no. of samples positive. n: no. of fish sampled. Group I, Batches 1 to 4: immersion-immunized and challenged with E. ictaluri, Batch 5: non-immunized control; Group II, Batch 1 and 2: intraperitoneally injected with E. ictaluri and F. columnare; Group III: i.p. injected with F. columnare; Group IV: spontaneously acquired infection with F. columnare

\begin{tabular}{|c|c|c|c|c|c|c|c|c|c|c|c|c|c|c|}
\hline \multirow[t]{3}{*}{ Group } & \multirow[t]{3}{*}{ Batch } & \multirow[t]{3}{*}{$\mathrm{n}$} & \multicolumn{6}{|c|}{ Bacteriological culture } & \multicolumn{6}{|c|}{ IFA test } \\
\hline & & & \multicolumn{2}{|c|}{ Kidney } & \multicolumn{2}{|c|}{ Brain } & \multicolumn{2}{|c|}{ Nares } & \multicolumn{2}{|c|}{ Kidney } & \multicolumn{2}{|c|}{ Brain } & \multicolumn{2}{|c|}{ Nares } \\
\hline & & & $E I$ & $F C$ & $E I$ & $F C$ & $E I$ & $F C$ & $E I$ & $F C$ & $E I$ & $F C$ & $E I$ & $F C$ \\
\hline \multirow{5}{*}{ Group I } & 1 & 5 & 5 & 0 & 5 & 0 & 4 & 0 & 5 & 0 & 3 & 0 & 3 & 0 \\
\hline & 2 & 6 & 6 & 0 & 6 & 0 & 5 & 0 & 6 & 0 & 4 & 0 & 5 & 0 \\
\hline & 3 & 10 & 10 & 0 & 10 & 0 & 8 & 0 & 9 & 0 & 5 & 0 & 7 & 0 \\
\hline & 4 & 14 & 14 & 0 & 14 & 0 & 9 & 0 & 13 & 0 & 10 & 0 & 8 & 0 \\
\hline & 5 & 12 & 0 & 0 & 0 & 0 & 0 & 0 & 0 & 0 & 0 & 0 & 0 & 0 \\
\hline \multirow[t]{2}{*}{ Group II } & 1 & 15 & 15 & 15 & 13 & 6 & 13 & 14 & 15 & 15 & 8 & 5 & 12 & 13 \\
\hline & 2 & 12 & 11 & 12 & 10 & 6 & 8 & 11 & 12 & 10 & 9 & 7 & 9 & 12 \\
\hline Group III & & 12 & 0 & 9 & 0 & 9 & 0 & 5 & 0 & 10 & 0 & 6 & 0 & 5 \\
\hline Group IV & & 15 & 0 & 15 & 0 & 6 & 0 & 9 & 0 & 13 & 0 & 3 & 0 & 8 \\
\hline
\end{tabular}


by culture as belonging to $E I$ or $F C$ on the basis of their morphological appearance on selective media, Gramstain characteristics, and the distinctive biochemical characteristics of each bacterium. The fatty acid methyl ester profiles further established the identity of each bacterium. Although occasionally commensal organisms were isolated on the culture media, these organisms were readily distinguished from $E I$ and/or $F C$ on the basis of the above tests. All fish in Group I, Batches 1 to 4 , that died $(\mathrm{n}=35)$ following experimental infection with E. ictaluri, yielded E. ictaluri from at least 1 of the 3 tissues sampled. A majority of the isolations were made from the kidney $(\mathrm{n}=35)$ and brain $(\mathrm{n}=35)$, with a moderate number $(n=26)$ of positive cultures from the nares. The samples that were positive by IFA test for the same group were 33 kidney, 22 brain and 23 nares. As expected, no F. columnare were detected in this group by either method. The control fish in Group I, Batch 5 ( $\mathrm{n}=12$ ), were negative for both organisms by bacteriological culture and IFA test. In Group II, Batches 1 and 2, E. ictaluri and F. columnare were isolated by culture from the following samples: kidney, $E I=26, F C=27$; brain, $E I=23, F C=12$; nares, $E I=21$, $F C=25$. The same 3 sites when tested by the IFA test yielded results that were somewhat similar (kidney, $E I=27, F C=25$; brain, $E I=17, F C=12$; nares,$E I=21$, $F C=25)$. Group III fish that were experimentally infected with $F$. columnare were positive for $F$. columnare only, as were fish in Group IV, which acquired spontaneous columnaris disease in a separate aquarium (Table 1). Epifluorescence microscopy revealed $E$. ictaluri as plump rods displaying an apple-green fluorescence color (stained with Alexa Fluor 488) (Fig. 1a), while $F$. columnare appeared as slender rods emitting a reddish fluorescence (stained with Alexa Fluor 594) (Fig. 1b). Smears that were positive for both E. ictaluri and $F$. columnare revealed the specific bacteria stained green or red with the respective fluorochromes (Fig. 1c). Smears made from known cultures of Escherichia coli mixed with Edwardsiella ictaluri (Fig. 2) and Yersinia ruckeri mixed with F. columnare (Fig. 3) revealed fluorescence specifically for the organisms against which the primary antibodies were developed. Some degree of fluorescence was observed with $E d$ wardsiella tarda in smears of E. ictaluri mixed with $E$. tarda and probed with MAb AA224 (Fig. 4). However, E. tarda emitted faint green fluorescence in contrast to the bright apple-green fluorescence emitted by E. ictaluri, which is readily distinguishable (Fig. 4).

The antigenic profile of 9 Edwardsiella ictaluri isolates probed with MAb AA224 and 9 Flavobacterium columnare isolates probed with polyclonal goat anti- $F$. columnare antibodies are shown in Figs. 5 \& 6 respectively. MAb AA224 reacted with epitopes distributed at apparent molecular mass positions of 70 and $12 \mathrm{kDa}$
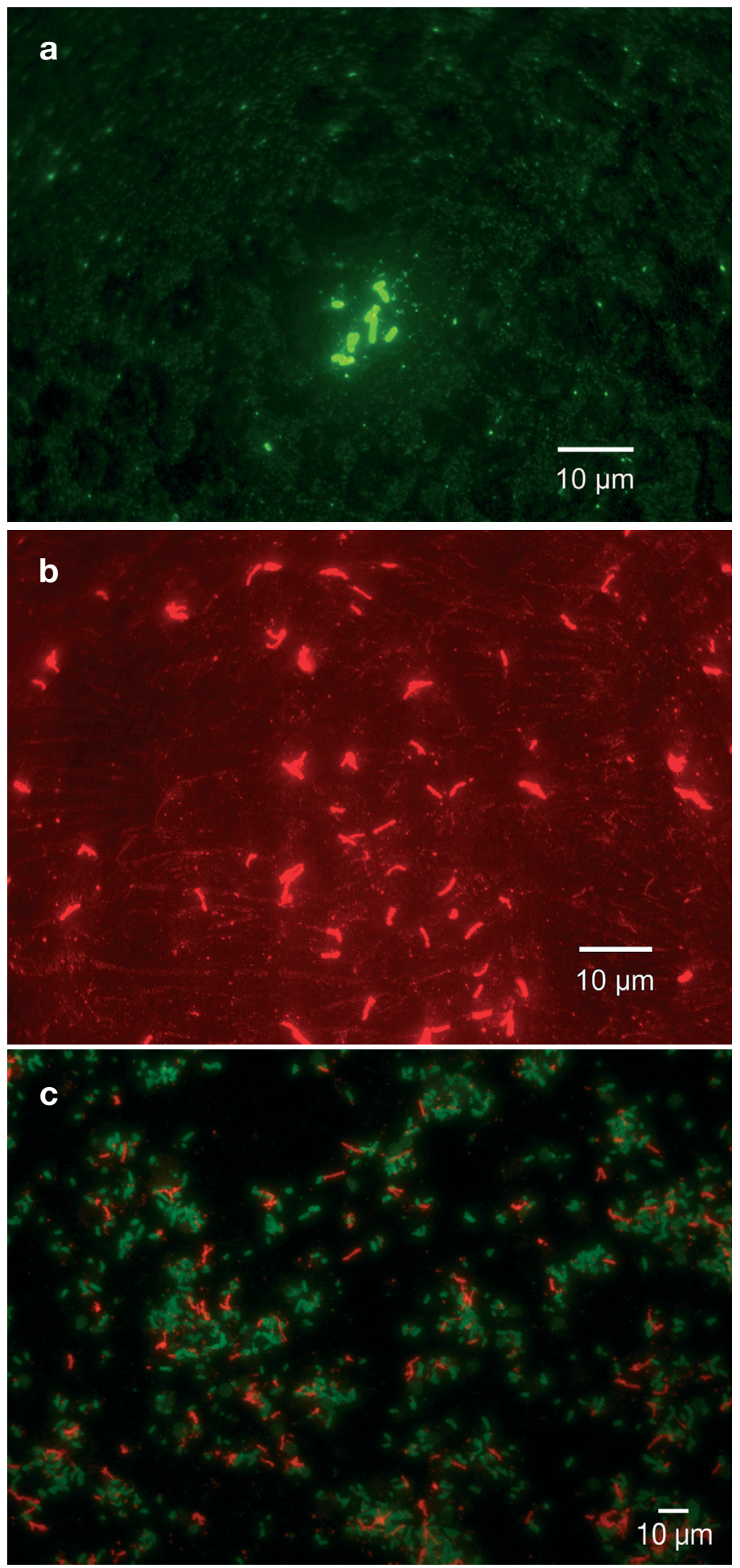

Fig. 1. Ictalurus punctatus. (a) Impression smear of brain tissue from fish infected with Edwardsiella ictaluri, emitting apple-green fluorescence of Alexa Fluor 488; (b) impression smear of kidney tissue from fish infected with Flavobacterium columnare, emitting reddish fluorescence of Alexa Flour 594; (c) impression smear of kidney tissue from fish simultaneously infected with $E$. ictaluri (emitting green fluorescence of Alexa Fluor 488) and F. columnare (emitting reddish fluorescence of Alexa Fluor 594). All under epifluorescence microscopy 

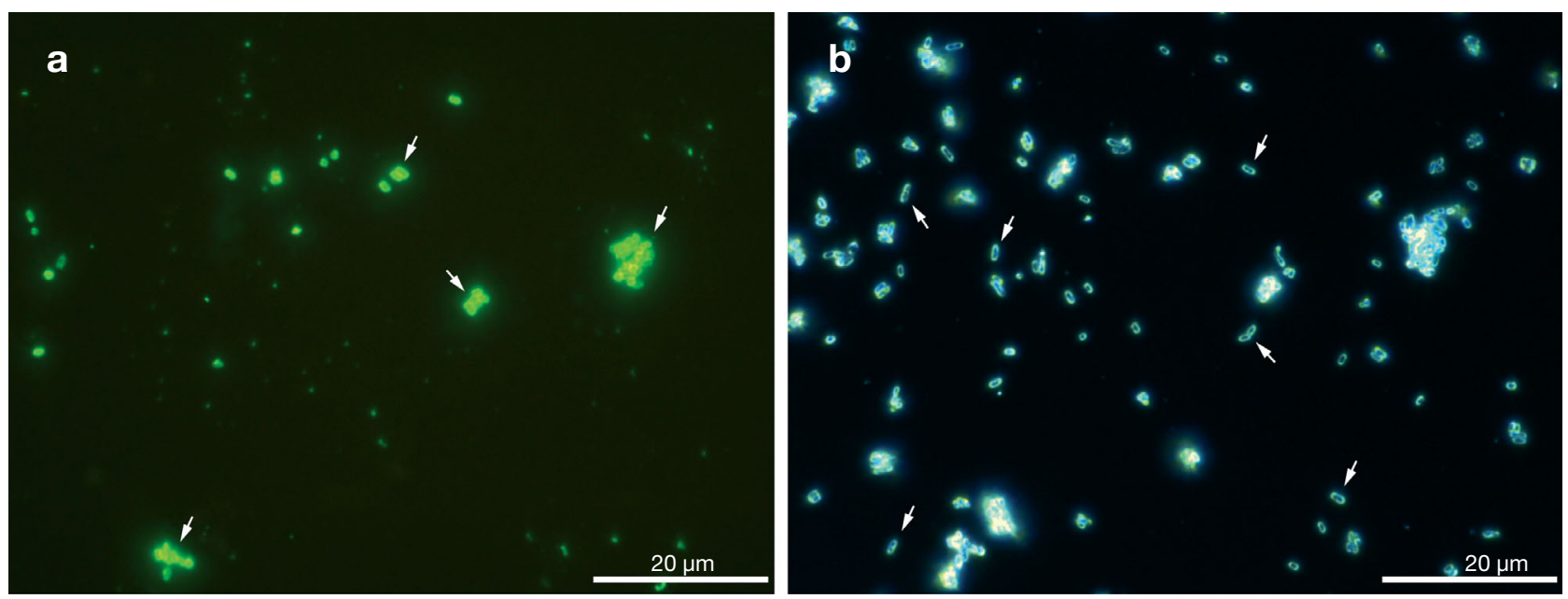

Fig. 2. Edwardsiella ictaluri and Escherichia coli. Smear from pure cultures mixed and treated with MAb AA224 and Alexa Flour 488conjugated second antibody. (a) E. ictaluri (arrows) emitting apple-green fluorescence, viewed with FITC/Texas Red, blue/green band-pass filters 'on'; (b) E. coli (arrows) in same field, viewed under white-light, with band-pass filters 'off'

in E. ictaluri and uniformly present among all isolates tested (Fig. 5), indicating that the MAb was able to detect a spectrum of E. ictaluri isolates. The polyclonal goat anti-F. columnare antibodies reacted strongly with an epitope at $66 \mathrm{kDa}$ that was present among all isolates tested, and also reacted with variable epitopes distributed at molecular mass positions between 50 and $25 \mathrm{kDa}$ among the $9 \mathrm{~F}$. columnare isolates (Fig. 6). Thus, the anti-F. columnare antibodies react with different isolates of $F$. columnare. Blots of protein profiles of select fish-pathogenic organisms (Aeromonas hydrophila, Streptococcus iniae, E. tarda and
Yersinia ruckeri) probed with MAb AA224 (Fig. 7), or polyclonal goat anti-F.columnare antibodies (Fig. 8) reacted specifically with the antigens of the homologous species of bacteria against which the respective antibodies were made.

The relative efficiency of the IFA test compared to bacteriological culture (accepted standard) for $E d$ wardsiella ictaluri and Flavobacterium columnare is summarized in Tables $2 \& 3$. Since EI was the only organism detected in Group I, Batches 1 to 4, and EI and FC were both detected in Group II, Batches 1 and 2, the efficiency of the IFA test for detection of EI was analyzed independently from that of $F C$ (Table 2) and the efficiency of the IFA test for detection of $F C$ among the 3 groups, II (Batches 1 and 2); III and IV, were analyzed separately (Table 3). Thus, the estimated sensitivity for $E I$ was $80.7 \%$ (95\% confidence interval $[\mathrm{CI}]=73.9$ to $86.4 \%$ ). For testing the null hypothesis $\left(H_{0}\right)$ that true sensitivity $\leq 75 \%$, the p-value was 0.05 and the estimated specificity for $E I$ was $83.9 \%$ (95\% CI $=71.7$ to $92.4 \%$ ). For testing the null hypothesis that true specificity $\leq 75 \%$, the observed level of significance was $p=0.08$. The estimated sensitivity of the IFA test for detection of FC (Groups II, III and IV) was $87.2 \%$ (95\% CI $=79.7$ to $92.6 \%$ ). For testing the null hypothesis that true sensitivity $\leq 75 \%$, the observed level of significance was $p=0.001$. The estimated specificity was $88.9 \%$ (95\% $\mathrm{CI}=75.9$ to $96.3 \%$ ). For testing the

Fig. 3. Flavobacterium columnare and Yersinia ruckeri. Smear from pure cultures mixed and treated with polyclonal goat anti-F. columnare antibodies and Alexa Flour 594-conjugated second antibody. (a) F. columnare (arrows) emitting red fluorescence viewed with FITC/Texas Red, blue/green band-pass filters 'on'; (b) presence of $Y$. ruckeri (arrows) in same field, viewed under white-light, with band-pass filters 'off' 


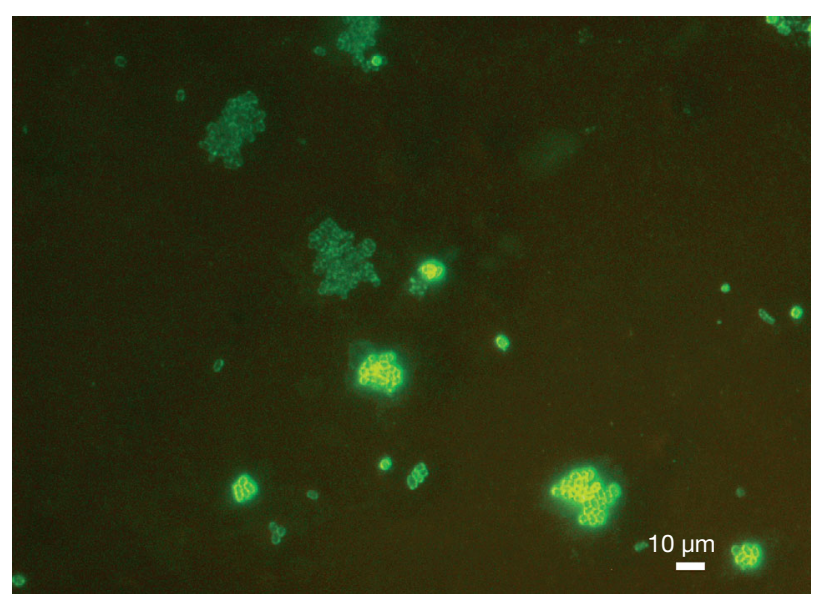

Fig. 4. Edwardsiella ictaluri and E. tarda. Smear from pure cultures mixed and treated with MAb AA224 and Alexa Flour 488-conjugated second antibody. E. tarda emitted faint green fluorescence in contrast to bright apple-green fluorescence of E. ictaluri, which is readily distinguishable

null hypothesis that true specificity $\leq 75 \%$, the observed level of significance was $p=0.018$. Overall, the PPV ranged between 90.8 and $96.2 \%$ for $E I$, while the NPV ranged between 31.3 and $66.7 \%$. For FC, PPV ranged between 95.2 and $95.3 \%$ and NPV between 72.7 and $73.7 \%$.

\section{DISCUSSION}

ESC (66.6\% of operations), columnaris disease (50.4\% of operations) and winter kill (32.9\% of operations) are the 3 most prevalent fish diseases in the USA (USDA 2003). Monetary losses attributed to disease range in the millions of dollars each year (Shoemaker

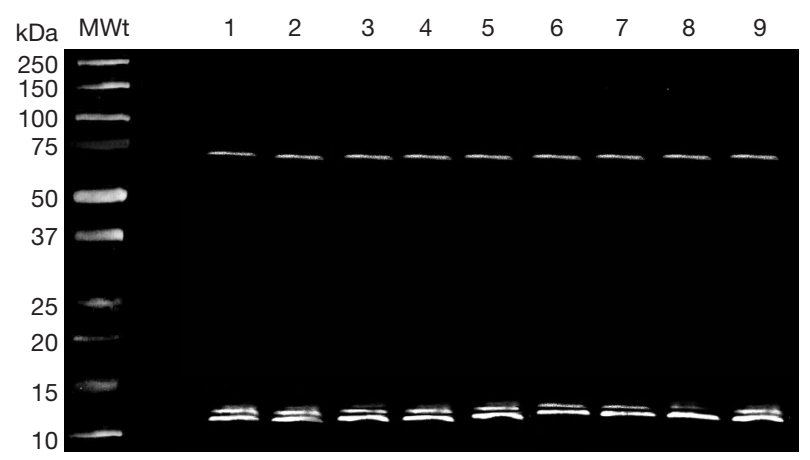

Fig. 5. Immunoblot of Edwardsiella ictaluri isolates. Lane 1: 016-S99-1911; 2: 017-S99-1914; 3: 013-S99-1908; 4: 033-S991760; 5: S-94-1051; 6: ALG-03-189; 7: ALG-03-190; 8: ALG99-407; 9: ALG-03-192 probed with MAb AA224. Antigenic epitopes at apparent molecular mass positions of 71 and $12 \mathrm{kDa}$ were detected in all isolates. Recombinant Precision Plus (BioRad) prestained molecular weight markers (MWt) are shown in Lane MWt

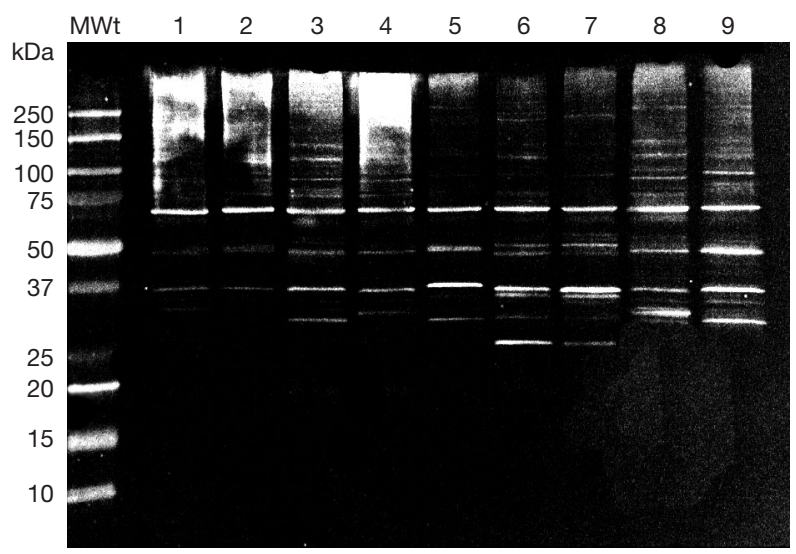

Fig. 6. Immunoblot of Flavobacterium columnare isolates. Lane 1: HS; 2: ARS-1; 3: ATCC-23463; 4: BioMed; 5: IR; 6: MS-02-475; 7: LSU; 8: GZ; 9: MS-02-467 probed with polyclonal goat anti-F. columnare antibodies. Prominent epitope at apparent molecular mass position of $66 \mathrm{kDa}$ was detected in all isolates, as were variable epitopes at other positions. MWT: molecular weight markers

et al. 2002). Since ESC and columnaris disease have been reported from countries where intensive aquaculture is practiced (Austin \& Austin 1999, Plumb 1999) it is reasonable to believe that disease due to Edwardsiella ictaluri and Flavobacterium columnare has great economic impact on the aquaculture industry worldwide. In freshwater aquaculture systems, fishes are farmed under intensive management conditions, with high stocking rates (15000 to $20000 \mathrm{fish} \mathrm{ha}^{-1}$ ) and covering extensive pond acreages (Jack et al. 1992). Under such conditions, the sudden outbreak of disease and its unchecked spread would be economically devastating, particularly because fish farmers operate within narrow profit margins and even a modest drop in production could be a threat to the viability of farms.

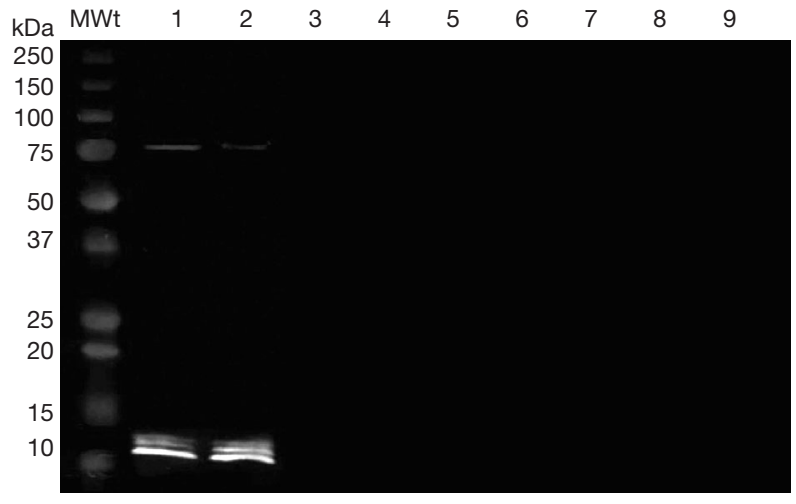

Fig. 7. Immunoblot of selected bacteria probed with MAb AA224. Lane 1: Edwardsiella ictaluri ALG-03-189; 2: E. ictaluri ALG-03-190; 3: Flavobacterium columnare ARS-1; 4: F. columnare LSU; 5: Aeromonas hydrophila K106K; 6: A. hydrophila C1B; 7: Streptococcus iniae; 8: E. tarda; 9: Yersinia ruckeri. MAb-recognized antigens of $E$. ictaluri are shown in Lanes 1 and 2. MWt: molecular weight markers 


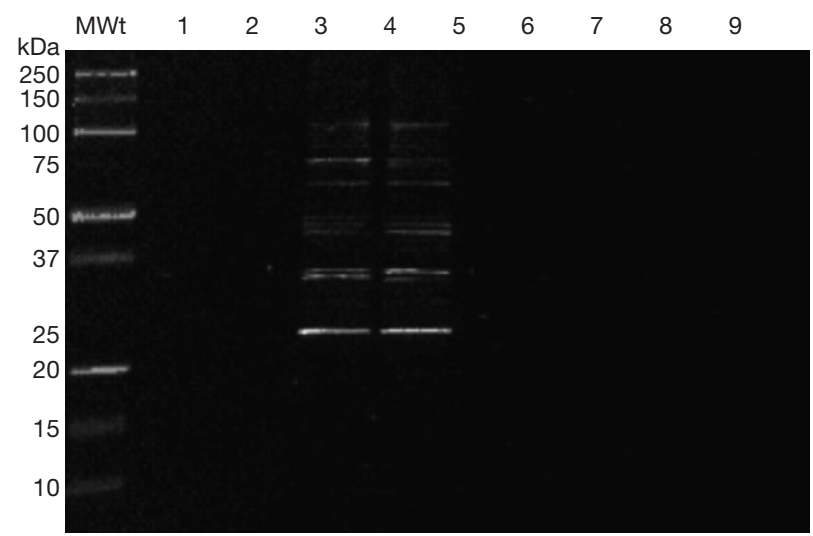

Fig. 8. Immunoblot of selected bacteria probed with polyclonal goat anti-Flavobacterium columnare antibody. Lanes as in Fig. 7. Antibody-recognized antigens of $F$. columnare are shown in Lanes 3 and 4
Thus, measures to aid the rapid diagnosis of disease are vital to allow for timely management decisions, an example being surveillance, to prevent the spread of infection from pond to pond or to neighboring farms, for rapid salvaging of uninfected stock, and for implementing preventative measures.

The IFA test has served as a rapid and efficient procedure for the diagnosis of several bacterial (Desmonts et al. 1990, Nakamura \& Bylund 1997), viral (Takimoto et al. 1991, Madeley \& Peiris 2002) and parasitic (Mayer \& Palmer 1996, Belem \& Pote 2001) diseases. Traditionally, culture techniques have been the standard against which other tests have been compared. In this study we compared bacteriological culture with the IFA test for simultaneous detection of Edwardsiella ictaluri and Flavobacterium columnare in 3 groups of experimentally infected catfish and a 4 th group with

Table 2. Ictalurus punctatus infected with Edwardsiella ictaluri. Estimate of indirect fluorescent antibody (IFA) test efficiency compared with bacteriological culture $(\mathrm{BC})$ for respective fish groups (see Table 1 for treaments). TP: True positive (TP) = IFA positive (+) and BC positive (+); FP: false positive (FP) = IFA positive (+) and BC negative $(-)$; FN: false negative (FN) = IFA negative $(-)$ and BC positive $(+)$; TN: true negative (TN) = IFA negative $(-)$ and BC negative $(-)$; Sens (sensitivity): conditional probability that a unit of analysis has a positive test result, given that disease is present; Spec (specificity): conditional probability that a unit of analysis has a negative test result, given that disease is not present; PPV: positive predictive value; NPV: negative predictive value; Agreement: overall proportion correctly classified, (TP + TN)/N (Greiner \& Gardner 2000)

\begin{tabular}{|lccccccccc|}
\hline $\begin{array}{l}\text { Group } \\
\text { Batch }\end{array}$ & $\begin{array}{c}\text { IFA+ BC+ } \\
\text { TP }\end{array}$ & $\begin{array}{c}\text { IFA+BC- } \\
\text { FP }\end{array}$ & $\begin{array}{c}\text { IFA- BC+ } \\
\text { FN }\end{array}$ & $\begin{array}{c}\text { IFA- BC- } \\
\text { TN }\end{array}$ & $\begin{array}{c}\text { Sens } \\
(\%)\end{array}$ & $\begin{array}{c}\text { Spec } \\
(\%)\end{array}$ & $\begin{array}{c}\text { PPV } \\
(\%)\end{array}$ & $\begin{array}{c}\text { NPV } \\
(\%)\end{array}$ & $\begin{array}{c}\text { Agreement } \\
(\%)\end{array}$ \\
\hline Group I & & & & & & & & \\
1 & 11 & 0 & 3 & 1 & 78.6 & 100.0 & 100.0 & 25.0 & 80.0 \\
2 & 14 & 1 & 3 & 0 & 82.4 & 0.0 & 93.3 & 0.0 & 77.8 \\
3 & 20 & 1 & 8 & 1 & 71.4 & 50.0 & 95.2 & 11.1 & 70.0 \\
4 & 30 & 1 & 7 & 4 & 81.1 & 80.0 & 96.8 & 36.4 & 81.0 \\
5 & 0 & 0 & 0 & 36 & - & 100.0 & - & 100.0 & 100.0 \\
$1-5$ combined & 75 & 3 & 21 & 42 & 78.1 & 93.3 & 96.2 & 66.7 & 83.0 \\
Group II & & & & & & & & \\
1 & 35 & 0 & 6 & 4 & 85.4 & 100.0 & 100.0 & 40.0 & 86.7 \\
2 & 24 & 6 & 5 & 1 & 82.8 & 14.3 & 80.0 & 16.7 & 69.4 \\
$1+2$ combined & 59 & 6 & 11 & 5 & 84.3 & 45.5 & 90.8 & 31.3 & 79.0 \\
Groups I + II combined & 134 & 9 & 32 & 47 & 80.7 & 83.9 & 93.7 & 59.5 & 81.5 \\
\hline
\end{tabular}

Table 3. Ictalurus punctatus infected with Flavobacterium columnare. Estimate of IFA test efficiency compared with bacteriological culture (BC). Abbreviations as in Table 2; treatments as in Table 1

\begin{tabular}{|c|c|c|c|c|c|c|c|c|c|}
\hline $\begin{array}{r}\text { Group } \\
\text { Batch }\end{array}$ & $\begin{array}{c}\mathrm{IFA}+\mathrm{BC}+ \\
\mathrm{TP}\end{array}$ & $\begin{array}{c}\mathrm{IFA}+\mathrm{BC}- \\
\text { FP }\end{array}$ & $\begin{array}{c}\text { IFA- BC+ } \\
\text { FN }\end{array}$ & $\begin{array}{c}\text { IFA- BC- } \\
\text { TN }\end{array}$ & $\begin{array}{c}\text { Sens } \\
(\%)\end{array}$ & $\begin{array}{c}\text { Spec } \\
(\%)\end{array}$ & $\begin{array}{l}\text { PPV } \\
(\%)\end{array}$ & $\begin{array}{l}\text { NPV } \\
(\%)\end{array}$ & $\begin{array}{c}\text { Agreement } \\
(\%)\end{array}$ \\
\hline \multicolumn{10}{|l|}{ Group II } \\
\hline 1 & 32 & 1 & 3 & 9 & 91.4 & 90.0 & 97.0 & 75.0 & 91.1 \\
\hline 2 & 27 & 2 & 2 & 5 & 93.1 & 71.4 & 93.1 & 71.4 & 88.9 \\
\hline $1+2$ combined & 59 & 3 & 5 & 14 & 92.2 & 82.4 & 95.2 & 73.7 & 90.1 \\
\hline Group III & 19 & 2 & 4 & 11 & 82.6 & 84.6 & 90.5 & 73.3 & 83.3 \\
\hline Group IV & 24 & 0 & 6 & 15 & 80.0 & 100.0 & 100.0 & 71.4 & 86.7 \\
\hline Groups II, III, IV combined & 102 & 5 & 15 & 40 & 87.2 & 88.9 & 95.3 & 72.7 & 87.7 \\
\hline
\end{tabular}


an aquarium-acquired spontaneous infection with $F$. columnare. Of the 3 groups intentionally infected, all fish tested by culture and IFA test yielded the homologous bacterium with which they had been infected. As expected, the control uninfected fish were discerned to be negative by both the culture and IFA tests. Some commensal organisms that were distinct from E. ictaluri and F. columnare appeared during culture, but these did not display any cross reactions with the antibodies used in the IFA test. Additionally, several Gramnegative organisms (Escherichia coli, Yersinia ruckeri, Pseudomonas aeruginosa, and Aeromonas hydrophila) that are likely to be present in aquaculture environments were tested and found negative in the IFA test. Faint fluorescence was observed with E. tarda, but this could be readily distinguished from the bright green fluorescence emitted by E. ictaluri. This may be due to the presence of some epitopes shared between these 2 Edwardsiella species, which have been shown to possess a high degree of similarity (Panangala et al. 2005). To ascertain that the antibodies were capable of detecting a broad spectrum of E. ictaluri and F. columnare isolates, representative isolates belonging to each species were examined by immunoblotting. The antibodies reacted with antigenic determinants present at distinctive molecular weight positions in all homologous isolates of the respective species tested. Klesius \& Horst (1991), tested MAb AA224 against 8 bacterial species associated with infections in channel catfish, and observed specific reactivity with only E. ictaluri by the indirect immunofluorescence assay. Among the infected organs (kidney, brain and nares) sampled, both E. ictaluri and F. columnare were detected more frequently in the kidney compared to the brain and nares. E. ictaluri homes into the kidney and brain (Baldwin \& Newton 1993, Nusbaum \& Morrison 1996, 2002) following entry through the nares or gills. Although columnaris disease has generally been noted for its characteristic superficial lesions, systemic infection due to $F$. columnare has also been documented (Hawke \& Thune 1992, Koski et al. 1993) and it is likely that in systemic infections, F. columnare are disseminated via the blood stream to internal organs (Pacha \& Ordal 1967, Thune \& Stanley 1993).

The IFA test compared favorably in sensitivity $(E I=80.7 \%, F C=87.2 \%)$ and specificity $(E I=83.9 \%$, $F C=88.9 \%$ ) with bacteriological culture. The PPV (i.e. the conditional probability of disease) of the IFA test was generally high, while the NPV (i.e. the conditional probability of no disease) was relatively low. In the context of sensitivity and specificity, the results of the present study are within the range generally considered efficient for diagnosis of disease (Greiner \& Gardner 2000, Bouma et al. 2001). Ainsworth et al. (1986) compared bacteriological culture with the IFA test for de- tection of Edwardsiella ictaluri in experimentally infected channel catfish and observed a 90.3\% correlation between the 2 tests. The IFA test has also been used for detection of E. ictaluri in channel catfish identified as asymptomatic carriers (Klesius 1992). Huh \& Wakabayashi (1987) observed a high degree of sensitivity and specificity in the IFA test compared with culture for detection of Flavobacterium spp. in both experimentally and naturally infected fishes, and Madetoja \& Wiklund (2002) claimed that the IFA test and the nested PCR technique were superior to the agar plate culture technique for rapid detection of F. psychrophilum in water samples from fish farms. The IFA test used in the present study employed a combination of antibody-conjugated fluorochromes (Alexa Fluor 488 and Alexa Fluor 594) with distinctive spectral properties for the simultaneous detection of E. ictaluri and $F$. columnare in the same host specimen. Since $E$. ictaluri and F. columnare are ubiquitous and could cohabit the same aquatic environment, co-infections or multiple infections in the same host by both organisms are not unusual (Wagner et al. 2002). In an extensive survey spanning $10 \mathrm{yr}$ (1979 to 1988), the Mississippi State fish-health diagnostic laboratories reported the isolation of more than a single bacterial species in many cases, with the occasional occurrence of multiple bacterial pathogens (Jack et al. 1992). Realistically, a test with the potential to rapidly detect multiple bacterial infections simultaneously would have a distinct advantage over cultural techniques, which take approximately 2 to $4 \mathrm{~d}$ to achieve at a definitive diagnosis. Double immunofluorescence staining techniques have been used for identification and simultaneous differentiation of several species in the genus Clostridium (Batty \& Walker 1965) and for the rapid detection of multiple respiratory viruses in clinical specimens (Landry \& Ferguson 2000). Several innovative developments such as specifically tailored filter sets for simultaneous detection of multiple fluorochromes, efficient means for retarding fading during microscopy, and the potency and specificity of antibody conjugates makes the IFA test an efficient, versatile tool for rapid diagnosis of ESC and columnaris disease.

Acknowledgements. The authors thank Drs. J. C. Dennis, V. Vodyanoy and O. Pustovyy of the Department of Anatomy, Physiology and Pharmacology, Auburn University, for their assistance with the microphotography. We also gratefully acknowledge the technical assistance of R. Wood and Mrs. W. P. Mumma and the staff of the AAHRU aquatic facility for daily care and monitoring of the fish. This work was supported by the USDA/Agricultural Research Service CRIS project \# 642032000-020-00Db. Mention of trade names or commercial products in this publication is solely for the purpose of providing specific information and does not imply recommendation or endorsement by the US Department of Agriculture. 


\section{LITERATURE CITED}

Ainsworth AJ, Capley G, Waterstreet P, Munson D (1986) Use of monoclonal antibodies in the indirect fluorescent antibody technique (IFA) for diagnosis of Edwardsiella ictaluri. J Fish Dis 9:439-444

Anderson JIW, Conroy DA (1969) The pathogenic Myxobacteria with special reference to fish disease. J Appl Bacteriol 32:30-39

Arias CR, Welker TL, Shoemaker CA, Abernathy JW, Klesius $\mathrm{PH}$ (2004) Genetic fingerprinting of Flavobacterium columnare isolates from cultured fish. J Appl Microbiol 97: $421-428$

Austin B, Austin DA (eds) (1999) Bacterial fish pathogens: disease of farmed and wild fish, 3rd edn. Praxis Publishing, New York

Bader JA, Shoemaker CA, Klesius PH, Connolly MA, Barbaree JM (1998) Genomic subtyping of Edwardsiella ictaluri isolated from diseased channel catfish by arbitrarily primed polymerase chain reaction. J Aquat Anim Health 10:22-27

Bader JA, Shoemaker CA, Klesius PH (2003) Rapid detection of columnaris disease in channel catfish (Ictalurus punctatus) with a new species-specific 16-S rRNA gene-based PCR primer for Flavobacterium columnare. J Microbiol Methods 52:209-220

Baldwin J, Newton JC (1993) Pathogenesis of enteric septicemia of channel catfish, caused by Edwardsiella ictaluri: bacteriologic and light and electron microscopic findings. J Aquat Anim Health 5:189-198

Batty I, Walker PD (1965) Colonial morphology and fluorescent labeled antibody staining in the identification of species of the genus Clostridium. J Appl Bact 28:112-118

Belem AM, Pote LM (2001) Portals of entry and systemic localization of proliferative gill disease organisms in channel catfish Ictalurus punctatus. Dis Aquat Org 48:37-42

Bernardet JF, Grimont PAD (1989) Deoxyribonucleic acid relatedness and phenotypic characterization of Flexibacter columnaris sp. nov., nom. rev., Flexibacter psychrophilus sp.nov., nom. rev., and Flexibacter maritimus Wakabayashi, Hikida, and Masumura (1986). Int J Syst Bacteriol 39:346-354

Bernardet JF, Sergers P, Vancanneyt M, Berthe F, Kersters K, Vandamme P (1996) Cutting the Gordian knot: emended classification and description of the genus Flavobacterium, emended description of the family Flavobacteriaceae, and proposal of Flavobacterium hydatis nom. nov. (Basonym, Cytophaga aquatilis Strohl and Tait 1978). Int J Syst Bacteriol 46:128-148

Bilodeau AL, Waldbieser GC, Terhune JS, Wise DJ, Wolters WR (2003) A real time polymerase chain reaction assay of the bacterium Edwardsiella ictaluri in channel catfish. J Aquat Anim Health 15:80-86

Bouma A, Stegeman JA, Engel B, de Kluijver EP, Elbers AR, De Jong MC (2001) Evaluation of diagnostic tests for the detection of classical swine fever in the field without a gold standard. J Vet Diagn Investig 13:383-388

Decostere A, Haesebrouck F, Devriese LA (1998) Characterization of four Flavobacterium columnare (Flexibacter columnaris) strains isolated from tropical fish. Vet Microbiol 62:35-45

Desmonts C, Minet J, Colwell R, Cormier M (1990) Fluorescent-antibody method useful for detecting viable but nonculturable Salmonella spp. in chlorinated wastewater. Appl Environ Microbiol 56:1448-1452

Durborow RM, Thune RL, Hawke JP, Camus AC (1998) Columnaris disease: a bacterial infection caused by Fla- vobacterium columnare. Publication no. 479, Southern Regional Aquaculture Centre, Stoneville, MI (available at govdocs.aquake.org/cgi/reprint/2003/727/7270100.pdf)

Farmer JJ III (2003) Enterobacteriaceae: introduction and identification. In: Murray PR, Baron EJ, Jorgensen $\mathrm{JH}_{\text {, }}$ Pfaller MA, Yolken RH (eds) Manual of clinical microbiology, 8th edn. American Society for Microbiology Press, Washington DC, p 636-653

Greiner M, Gardner IA (2000) Epidemiologic issues in the validation of veterinary diagnostic tests. Prev Vet Med 45: $3-22$

Hawke JP, Thune RL (1992) Systematic isolation and antimicrobial susceptibility of Cytophaga columnaris from commercially reared channel catfish. J Aquat Anim Health 4: 109-113

Huh GJ, Wakabayashi H (1987) Detection of Flavobacterium $\mathrm{sp}$., a pathogen of bacterial gill disease using indirect fluorescent antibody technique. Fish Pathol 22:215-220

Humphrey JD, Lancaster C, Gudkovs N, McDonald W (1986) Exotic bacterial pathogens Edwardsiella tarda and Edwardsiella ictaluri from imported ornamental fish Beta splendens and Puntius conchonis, respectively: isolation and quarantine significance. Aust Vet J 63:369-371

Jack SW, Taylor PW, Crosby MD, Freund J, MacMillan JR, Durborrow RM (1992) Summary of bacterial isolates from farm-reared channel catfish (1979-1988). J Vet Diagn Investig 4:193-195

Kasornchandra J, Rogers WA, Plumb JA (1987) Edwardsiella ictaluri from walking catfish, Clarias batrachus L., in Thailand. J Fish Dis 10:137-138

Klesius PH (1992) Carrier state of Edwardsiella ictaluri in channel catfish, Ictalurus punctatus. J Aquat Anim Health 4:227-230

Klesius PH (1993) Rapid enzyme-linked immunosorbent tests for detecting antibodies to Edwardsiella ictaluri in channel catfish, Ictalurus punctatus, using exoantigen. Vet Immunol Immunopathol 36:359-368

Klesius PH, Horst MN (1991) Characterization of a major outer-membrane antigen of Edwardsiella ictaluri. J Aquat Anim Health 3:181-187

Klesius PH, Lovy J, Evans J, Arias C (2003) Isolation of Edwardsiella ictaluri from tadpole madtom in a Southwestern New Jersey river. J Aquat Anim Health 15: 295-301

Koski P, Hiervela-Koski V, Bernardet JF (1993) Flexibacter columnaris infection in artic char (Salvelinus alpinus L.). First isolation in Finland. Bull Eur Assoc Fish Pathol 31: $66-69$

Laemmli UK (1970) Cleavage of structural proteins during the assembly of the head of bacteriophage T4. Nature 227: 680-685

Landry ML, Ferguson D (2000) SimulFluor respiratory screen for rapid detection of multiple respiratory viruses in clinical specimens by immunofluorescence staining. J Clin Microbiol 38:708-711

Madeley CR, Peiris JSM (2002) Methods in virus diagnosis: immunofluorescence revisited. J Clin Virol 25:121-134

Madetoja J, Wiklund T (2002) Detection of the fish pathogen Flavobacterium psychrophilum in water from fish farms. Syst Appl Microbiol 25:259-266

Mayer CL, Palmer CJ (1996) Evaluation of PCR, nested PCR, and fluorescent antibodies for detection of Giardia and Cryptosporidium species in wastewater. Appl Environ Microbiol 62:2081-2085

Nakamura RM, Bylund DJ (1997) Fluorescence immunoassays. In: Rose NR, deMacario EC, Folds JD, Lane HC, Nakamura RM (eds) Manual of clinical laboratory 
immunology, 5th edn. American Society for Microbiology Press, Washington, DC, p 39-48

Nusbaum KE, Morrison EE (1996) Entry of ${ }^{35}$ S-labeled Edwardsiella ictaluri into channel catfish. J Aquat Anim Health 8:146-149

Nusbaum KE, Morrison EE (2002) Edwardsiella ictaluri bacteraemia elicits shedding of Aeromonas hydrophila complex in latently infected channel catfish, Ictalurus punctatus (Rafinesque). J Fish Dis 25:343-350

Pacha RE, Ordal EJ (1967) Histopathology of experimental columnaris disease in young salmon. J Comp Pathol 77: 419-423

Panangala VS, vanSanten VL, Shoemaker CA, Klesius PH (2005) Analysis of 16S-23S spacer regions of the rRNA operons in Edwardsiella ictaluri and Edwardsiella tarda. J Appl Microbiol 99:657-669

Plumb JA (1999) Health maintenance and principal microbial diseases of cultured fish. Iowa State University Press, Ames, IA

Plumb JA, Sanchez DJ (1983) Susceptibility of five species of fish to Edwardsiella ictaluri. J Fish Dis 6:261-266

Plumb JA, Vinitnantharat S (1989) Biochemical, biophysical, and serological homogeneity of Edwardsiella ictaluri. J Aquat Anim Health 1:51-56

Schreckenberger PC, Daneshvar MI, Weyant RS, Hollis DG (2003) Acinetobacter, Achromobacter, Chryseobacterium, Moraxella, and other nonfermenative Gram-negative rods. In: Murry PR, Baron EJ, Jorgensen JH, Pfaller MA, Yolken RH (eds) Manual of clinical Microbiology, Vol 1. 8th edn. American Society for Microbiology Press, Washington, DC, p 749-779

Shieh HS (1980) Studies on the nutrition of a fish pathogen, Flexibacter columnaris. Microbios Lett 13:129-133

Shoemaker CA, Klesius PH, Evans JJ (2002) In ovo methods for utilizing the modified live Edwardsiella ictaluri vaccine against enteric septicemia in channel catfish. Aquaculture 203:221-227

Shoemaker CA, Shelby RA, Klesius PH (2003) Development of an indirect ELISA to detect humoral response to Flavobacterium columnare infections of channel catfish, Ictalurus punctatus. J Appl Aquacult 14:43-52

Shoemaker CA, Arias CR, Klesius PH, Welker TL (2005) Technique for identifying Flavobacterium columnare using whole cell fatty acid profiles. J Aquat Anim Health 17: $267-274$

Editorial responsibility: Donald Evans, Athens, Georgia, USA
Shotts EB, Waltman WD (1990) A medium for the selective isolation of Edwardsiella ictaluri. J Wildl Dis 26:214-218

Smith PK, Krohn RI, Hermanson GT, Mallia AK and 6 others (1985) Measurement of protein using bicinchronic acid. Anal Biochem 150:76-85

Snedecor GW, Cochran WG (1989) Statistical methods, 8th edn. Iowa State University Press, Ames, IA

Takimoto S, Grandien M, Ishida MA, Pereira MS, Paiva TM, Ishimaru T, Makita EM, Martinez CH (1991) Comparison of enzyme-linked immunosorbent assay, indirect immunofluorescence assay, and virus isolation for detection of respiratory viruses in nasopharyngeal secretions. J Clin Microbiol 29:470-474

Thune RL, Stanley LA (1993) Pathogenesis of Gram-negative bacterial infections in warmwater fish. Annu Rev Fish Dis 3:37-68

Towbin H, Staehelin T, Gordon J (1979) Electrophoretic transfer of proteins from polyacrylamide gels to nitrocellulose sheets: procedure and some applications. Proc Natl Acad Sci USA 76:4350-4354

Triftshauser C, Hayden DW, Beutner EH (1970) Procedures for the immunization of goats with human immunoglobulins and complement. Int Arch Allergy Appl Immunol 38: $315-319$

USDA (United States Department of Agriculture) (2003) Part2: Reference of food size catfish health and production practices in the United States. USDA, Animal and Plant Health Inspection Service, Veterinary Services, National Animal Health Monitoring System, Publ. No. N407.1103, Fort Collins, CO

Wagner BA, Wise DJ, Khoo LH, Terhune JS (2002) The epidemiology of bacterial disease in food-size channel catfish. J Aquat Anim Health 14:263-272

Waterstrat P, Ainsworth J, Capley G (1989) Use of an indirect enzyme-linked immunosorbent assay (ELISA) in the detection of channel catfish Ictalurus punctatus (Rafinesque), antibodies to Edwardsiella icataluri. J Fish Dis 12:87-94

Welker TL, Shoemaker CA, Arias CR, Klesius PH (2005) Transmission and detection of Flavobacterium columnare in channel catfish Ictalurus punctatus. Dis Aquat Org 63: 129-138

Wise DJ, Schwedler TE, Otis DL (1993) Effects of stress on susceptibility of naïve channel catfish in immersion challenge with Edwardsiella ictaluri. J Aquat Anim Health 5: 92-97

Submitted: June 6, 2005; Accepted: October 4, 2005

Proofs received from author(s): February 2, 2006 